\title{
THE INTERACTIVE EFFECT OF PHOSPHORUS AND NITROGEN ON "IN VITRO" SPORE GERMINATION OF GLOMUS ETUNICATUM BECKER \& GERDEMANN, ROOT GROWTH AND MYCORRHIZAL COLONIZATION
}

\author{
Wellington Bressan* \\ Embrapa Milho e Sorgo, Departamento de Microbiologia, Sete Lagoas, MG, Brasil \\ Submitted: August 21, 2000; Returned to authors for corrections: November 10, 2000; Approved: September 03, 2001

\begin{abstract}
The effects of $\mathrm{P}$ and $\mathrm{N}$ amendment and its interactions on spore germination, root growth and colonized root length by Glomus etunicatum Becker \& Gerdemann (INVAM S329) was studied "in vitro" in RiT - DNA transformed roots of Anthylis vulneraria sub sp. Sampaiana (Kidney vetch). Three N media concentrations $(5,10$ and $50 \mathrm{mg} / \mathrm{l})$ at $\mathrm{P}$ constant level $(2 \mathrm{mg} / \mathrm{l})$ and three $\mathrm{P}$ media concentrations $(2,10$ and $20 \mathrm{mg} / \mathrm{l})$ at $\mathrm{N}$ constant level $(5 \mathrm{mg} / \mathrm{l})$ were utilized as a treatment. Bécard \& Fortin medium was used as a basal medium for root growth and colonized root length, and water/agar $(0.8 \%)$ media was the control for spore germination. Spore germination of G. etunicatum at low $\mathrm{P}$ level was reduced by $\mathrm{N}$ addition in relation to the control media, and at low $\mathrm{N}$ level addition of $\mathrm{P}$ stimulated spore germination. Total root length was stimulated by $\mathrm{N}$ addtion at low P level, but no significant difference ( $\mathrm{p} £ 0.05$ ) was observed between 10 and $50 \mathrm{mg} / \mathrm{l}$ of N. P addition at low $\mathrm{N}$ level media also stimulated total root growth, and a significant difference (p£0.05) was observed among $\mathrm{P}$ concentrations. Colonized root length by G. etunicatum increased significantly ( $\mathrm{p} £ 0.05)$ with $\mathrm{P}$ additions at low $\mathrm{N}$ levels. Under low P level no significant differences was found between 10 and $50 \mathrm{mg} / \mathrm{l}$ of $\mathrm{N}$. These results demonstrate that the interaction between $\mathrm{P}$ and $\mathrm{N}$ affect differently spore germination, root growth and colonized root lenght.
\end{abstract}

Key words: Mycorrhiza, Glomus etunicatum, spore germination, root growth, root colonization.

\section{INTRODUCTION}

Arbuscular mycorrhizal fungi (AMF) are associated with the roots of nearly all agronomically important crop plants. The phosphorus (P) status of the soil has been reported to affect the ability of AMF fungi to colonize the root, and its addition to the soil affects root colonization by reducing penetration points $(23,25)$, depressing the development of internal and external hypha (1) and sporulation (18). Several reports $(16,26)$ have measured total root length and infected root length per plant and found that $\mathrm{P}$ stimulated root growth while having no effect on the length of infected root per plant. A result root colonization was reduced emphasizing the importance of assessing root growth in mycorrhizal studies (5).
Increase of available $\mathrm{P}$ levels in the soil or in the plant is frequently associated with the reduction in the root colonization by AMF as a result of less carbohydrate within the roots (27) or due to reducing the external mycelium growth in the soil at the lag phase of mycorrhiza formation (16) or the number of entry points in the roots (2). Bruce et al. (5) concluded that at very early stages of colonization P exerts its effect via reduced growth of infection units, and in P-deficient plants root colonization increases almost linearly with time and is substantially reduced by $\mathrm{P}$ amendment. However, small additions of $\mathrm{P}$ to low available $P$ soil can increase root colonization (4). When $P$ limits the growth of plants, infection of roots by AMF may lead to an increase in plant growth through an improved uptake of P (13). Mycorrhiza formation by Scutellospora calospora was unaffected by the

\footnotetext{
* Corresponding author. Mailing address: Embrapa Milho e Sorgo, Departamento de Microbiologia. 35701-970, Sete Lagoas, MG, Brasil. E-mail: bressan@cnpms.embrapa.br
} 
addition of $\mathrm{P}$ to the soil, whilst Glomus sp. was observed to decrease in both percent colonization and mycorhizal root length with the addition of $\mathrm{P}$ to the soil (19).

The nitrogen $(\mathrm{N})$ concentration in the soil or in the root tissue has been reported to affect root colonization, though less frequently than P. Most of the studies have been developed either in relation to the $\mathrm{N}$ source or in relation with $\mathrm{P}$ amendement. Coxwell and Johnson (7) reported that $\mathrm{N}$ source had little influence on root colonization of Pittosporum tobira (Thunb.) W.T. Aiton (Pittosporaceae) by Glomus mosseae Nicolson \& Gerdemann. Heijne et al. (14) showed that AMF colonization of Arnica montana L. and Hieracium pilosella L. were not affected by additional ammonium sulfate, while Antennaria dioica (L.) Gaertner increased with increasing concentrations of ammonium sulfate. Mosse (17) suggested that extra N slowed down the decline of root colonization by $\mathrm{AMF}$ at high $\mathrm{P}$ levels in onion. A reduced root colonization of ryegrass by Gigaspora margarita Becker \& Hall due to the addition of $\mathrm{NH}_{4}{ }^{+}$and $\mathrm{NO}_{3}{ }^{-}$ at $\mathrm{P}$ concentrations above the critical level for ryegrass was reported by Buwalda and Goh (6). In contrast, Hepper (15) reported increased root colonization of lettuce roots by Glomus mosseae at three $\mathrm{P}$ levels with increasing $\mathrm{NO}_{3}{ }^{-}$concentration.

The objective of this work was to study the interactive effects of $\mathrm{P}$ and $\mathrm{N}$ on spore germination of G.etunicatum, root growth and colonized root length by AMF.

\section{MATERIALS AND METHODS}

The factorial experiment had a completely randomized design with two treatments ( $\mathrm{P}$ constant and $\mathrm{N}$ constant): three different $\mathrm{N}$ concentrations $(5,10$ e $50 \mathrm{mg} / \mathrm{l})$ were considered within $\mathrm{P}$ constant $(2 \mathrm{mg} / \mathrm{l})$ treatment and three different $\mathrm{P}$ concentration $(2,10$ e $20 \mathrm{mg} / \mathrm{l})$ were utilized within $\mathrm{N}$ constant $(5 \mathrm{mg} / \mathrm{l})$ treatment. Concentrations of $\mathrm{P}$ and $\mathrm{N}$ at constant level were considered as a low level for these nutrients. The periods of evaluations were: 2, 4, 6, 8, 10, 15 and 20 days after roots plating. Five replicates for each P x N and N x P were utilized. Bécard and Fortin (3) medium was utilized as a basal medium (mg/l): $\mathrm{MgSO}_{4} .7 \mathrm{H}_{2} 0,731 ; \mathrm{KNO}_{3}$, 80; $\mathrm{KCl}, 65 ; \mathrm{KH}_{2} \mathrm{PO}_{4}, 4.8 ; \mathrm{Ca}\left(\mathrm{NO}_{3}\right)_{2}$. $4 \mathrm{H}_{2} \mathrm{O}, 288$; NaFeEDTA, 8 ; KI, $0.75 ; \mathrm{MnCl}_{2} .4 \mathrm{H}_{2} 0,6 ; \mathrm{Zn} \mathrm{SO}$. $7 \mathrm{H}_{2} 0,2.65 ; \mathrm{H}_{3} \mathrm{BO}_{3}, 1.5 ; \mathrm{Cu} \mathrm{SO}_{4} .5$ $\mathrm{H}_{2} \mathrm{O}, 0.13 ; \mathrm{Na}_{2} \mathrm{MoO}_{4} .2 \mathrm{H}_{2} \mathrm{O}, 0.0024$; Glycine, 3.0; thiamine hydrochloride, 0.1 ; pyridoxine hydrochloride, 0.1 ; nicotinic acid, 0.5; myo inositol, 50; bacto agar, 10.000; sucrose, 8.0.

Spores of Glomus etunicatum Becker and Gerd (isolate INVAM S329) were recovered from soil by wet-sieving and decanting technique (10) and centrifugation in sucrose $50 \%$. Recovered spores were surface disinfested during five minutes in a $10 \%$ solution of Chlorox plus Twin 20 (1 drop/100 ml). After disinfestation spores were rinsed five times in sterile distilled water. Three pieces $(30 \mathrm{~mm})$ of RiT-DNA transformed roots of Anthylis vulneraria sub sp. Sampaiana (Kidney vetch) were placed in Petri dishes (100 x $15 \mathrm{~mm}$ ) containing solid media (3) modified according to $\mathrm{P}$ and $\mathrm{N}$ concentrations. Ten disinfested spores were placed about $5 \mathrm{~mm}$ to each piece of transformed root. The culture of $A$. vulneraria transformed roots by Agrobacterium rhizogenes were maintained in a solid media (3). Water/agar $(0.8 \%)$ medium was utilized as a control for spores germination.

Plates were inculated at $26 \pm 2^{\circ} \mathrm{C}$ in the dark during 20 days. Evaluations of spore germination and root lenght were made every two days from plating, under a microscope. Total root lenght and root colonization were evaluated after 20 days from plating. Roots were removed gently from the plates and washed with distilled water. Then, they were cleared in $10 \% \mathrm{KOH}$, stained with $0.05 \%$ trypan blue (20) and total and colonized root length were estimated by the gridline-intersect method (12). The data were analysed using the general linear model (GLM) procedure of SAS (22). Significance of treatments were evaluated by Duncan's test. Root colonization percentage was arc sine transformed prior to running the GLM procedure.

\section{RESULTS AND DISCUSSION}

Nitrogen concentration in the media has been reported to have little or no effect on spore germination $(8,20)$. In this work, although spore germination increased in all different media composition, over the whole period of assessment, addition of $\mathrm{N}$ to the media at low $\mathrm{P}$ concentration decrease spore germination of G. etunicatum. However, within $\mathrm{N}$ treatments, spore germination was higher in the medium containing lower $\mathrm{N}$ amendment (5 mg/l) (Fig. 1A). Significant difference ( $\mathrm{p} £ 0.05$ ) was observed between the media amended with $\mathrm{N}$ and control medium (water/agar). Although spore germination was higher in low $\mathrm{N}$ medium, it was lower than the control (Fig. 1A). However, transformed root growth and total root length of $A$. vulneraria did not differ significantly $(\mathrm{p} £ 0.05)$ for the media amended with 10 and $50 \mathrm{mg} / \mathrm{l}$ of $\mathrm{N}$ at 20 days after plating (Table 1). Lower total root length was observed at lower $\mathrm{N}$ media (5 $\mathrm{mg} / \mathrm{l})$. Early studies in solution culture (11), and later studies in soil and vermiculite (9) did not show root stimulation when only $\mathrm{N}$ was present in the media, but a dense mass of silky roots developed with the amendment of P. Increasing the concentration of $\mathrm{N}$ in the media resulted in significant $(\mathrm{p} £ 0.05)$ increase in colonized root lenght by G. etunicatum. However in this study no significant difference was found between the media amended with 10 and $50 \mathrm{mg} / \mathrm{l}$ of $\mathrm{N}$.

Spore germination of G. etunicatum in the media with low N concentration and amended with different $\mathrm{P}$ concentrations showed significant differences ( $\mathrm{p} £ 0.05)$ among $\mathrm{P}$ amendments. The effect of increasing $P$ concentration can be seen in Fig. 1B. Wilson et al. (28) reported that the spore germination was estimulated when the soil was amended with a level of P sufficient to overcome the $\mathrm{P}$ competition with other soil microorganism. Siqueira et al. (24) reported that small amounts of $\mathrm{P}$ to either soil 
Table 1. "In vitro" root length and mycorrhizal colonized root length of Anthylis vulneraria by G. etunicatum in different $\mathrm{P}$ and $\mathrm{N}$ levels at 20 days after plating. Means of 15 replicates.

\begin{tabular}{ccccc}
\hline \multirow{2}{*}{$\begin{array}{c}\text { P and N } \\
\text { Treatments }(\mathrm{mg} / \mathrm{l})\end{array}$} & \multicolumn{2}{c}{ P constant level $(2 \mathrm{mg} / \mathrm{l})$} & \multicolumn{2}{c}{ N constant level $(5 \mathrm{mg} / \mathrm{l})$} \\
\cline { 2 - 5 } & $\begin{array}{c}\text { Total root length } \\
(\mathrm{cm})\end{array}$ & $\begin{array}{c}\text { Colonized root length } \\
(\mathrm{cm})\end{array}$ & $\begin{array}{c}\text { Total root length } \\
(\mathrm{cm})\end{array}$ & $\begin{array}{c}\text { Colonized root length } \\
(\mathrm{cm})\end{array}$ \\
\hline $\mathrm{N}_{5}$ & $7.2 \mathrm{~b}$ & $1.6 \mathrm{~b}$ & ---- & ---- \\
$\mathrm{N}_{10}$ & $7.7 \mathrm{ab}$ & $2.8 \mathrm{a}$ & --- & ---- \\
$\mathrm{N}_{50}$ & $8.0 \mathrm{a}$ & $2.5 \mathrm{a}$ & --- & $1.6 \mathrm{c}$ \\
& & & $7.2 \mathrm{c}$ & $5.2 \mathrm{~b}$ \\
$\mathrm{P}_{2}$ & ---- & ---- & $12.5 \mathrm{~b}$ & $7.4 \mathrm{a}$ \\
$\mathrm{P}_{10}$ & --- & ---- & $14.5 \mathrm{a}$ & \\
$\mathrm{P}_{20}$ & --- & - &
\end{tabular}

Means in the columns followed of the same letter do not differ siginificantly ( $\mathrm{p} £ 0,05$ ) by Duncan's test.
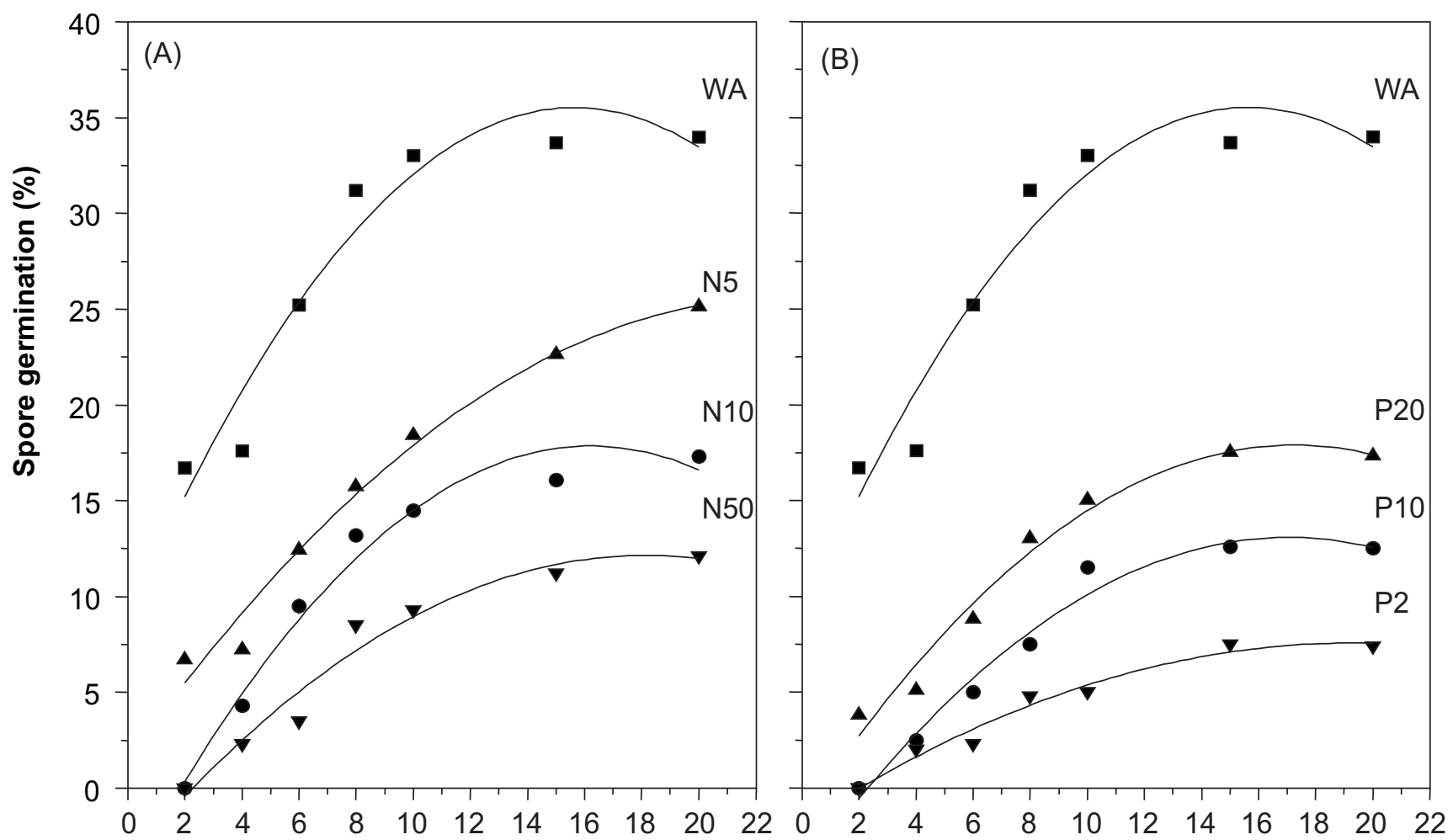

Days from plating

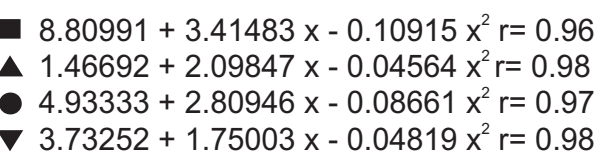

$8.80991+3.41483 x-0.10915 x^{2} r=0.97$

$\Delta 1.52848+2.25157 \mathrm{x}-0.06527 \mathrm{x}^{2} \mathrm{r}=0.98$

- $4.43822+2.05652 x-0.06036 x^{2} r=0.98$

$1.89584+0.98032 x-0.02538 x^{2} r=0.97$

Figure 1. Spore germination of G. etunicatum. (A) media with different $\mathrm{N}$ concentrations $(5,10 \mathrm{and} 50 \mathrm{mg} / \mathrm{l})$ at low $\mathrm{P}$ level $(2.0 \mathrm{mg} / \mathrm{l})$. (B) media with different $\mathrm{P}$ concentrations $(2,10$ and $20 \mathrm{mg} / \mathrm{l})$ at low $\mathrm{N}$ level $(5.0 \mathrm{mg} / \mathrm{l})$. WA (water/agar medium). 
or agar media improved spore germination and germ tube growth. Opposite results were obtained by Pons and Gianinazzi-Pearson (21). The results obtained in this experiment showed that the addition of $\mathrm{P}$ to the medium increases spore germination in $\mathrm{N}$ limiting conditions. However, as reported by Siqueira et al. (24) the spore reserve is utilized to supply enough nutrition to the process of spore germination. The higher number of spore germination observed in water/agar medium, as compared to the basal media may be explained by the presence of some nutrient either/or its concentration in the basal media which could have inhibited the spore germination. Similar results were observed by Hepper (15) for Endogone sp. spore germination in White's medium.

Phosphorus addition to low $\mathrm{N}$ media stimulated the transformed root lenght and total root growth (Table 1) Root lenght increased until 10 days from plating for all media and tended to be stationary from this period. This effect may have been caused by a decrease in nutrients availability in the media due to root uptake. Within the range of the $\mathrm{P}$ utilized, the addition of $\mathrm{P}$ to the media promoted significant $(\mathrm{p} £ 0.05)$ increase in the total root length (Table 1). The highest total root length was observed at high $\mathrm{P}$ amendment, indicating that at low $\mathrm{N}$ concentration the addition of $\mathrm{P}$ can lead to an increase in the total root growth. The colonized root growth by G. etunicatum showed the same trend. Highest colonized root growth at low $\mathrm{N}$ concentration was verified in the highest P level. Although, several workers have reported that $\mathrm{P}$ stimulated the total root length leading to a reduction in total length of infected root (27), the data obtained in this experiment showed an increase in the colonized root lenght with $\mathrm{P}$ addition. Bruce et al. (5) concluded that at very early stages of colonization, $\mathrm{P}$ exerts its effect via reduced growth on infection units, and at later stages, an increase in the root growth and low rates of formation of secondary infection also contribute to the low values of percent colonization. The conflicting results among the data obtained in this experiment and the data reported in the literature could be explained by differences in the conditions in which these experiments were carried out. Compared to soil condition studies, the levels of P utilized under "in vitro" conditions were relatively lower and lead to an increase in the root colonization by $G$. etunicatum.

\section{CONCLUSIONS}

Under "in vitro" conditions and low $\mathrm{P}$ concentrations addition of $\mathrm{N}$ to the media reduced spore germination of $G$. etunicatum, stimulated root length, colonized root length and increased total root length. Under low $\mathrm{N}$ concentration, addition of $\mathrm{P}$ stimulated spore germination, root length, colonized root length and increased total root lenght.

\section{RESUMO}

\section{Efeito interativo do fósforo e nitrogênio na germinação de esporos de Glomus etunicatum Becker \& Gerdemann, crescimento de raízes e colonização micorrízica "in vitro"}

Os efeitos da adição de $\mathrm{P}$ e $\mathrm{N}$ e suas interações sobre a germinação de esporos, crescimento e extensão de raízes de Anthylis vulneraria sub sp. Sampaiana (Kidney vetch) RiTDNA transformadas e colonizadas por Glomus etunicatum Becker \& Gerdemann (INVAM S329) foram estudadas em condições "in vitro". Em meios com baixo nível de P (2 mg/l) foram utilizadas três concentrações de $\mathrm{N}(5,10$ e $50 \mathrm{mg} / \mathrm{l})$ e em baixo nível de $\mathrm{N}(5 \mathrm{mg} / \mathrm{l})$ foram utilizadas três concentrações de $\mathrm{P}(2,10$ e $20 \mathrm{mg} / \mathrm{l})$. O meio de Bécard e Fortin foi utilizado como meio básico para o crescimento das raízes e colonização por $G$. etunicatum. O meio agar-água $(0,8 \%)$ foi considerado como controle para a germinação dos esporos. A germinação dos esporos de Glomus etunicatum em meios com baixo nível de P foi diminuída pela adição de $\mathrm{N}$ em relação ao meio de controle, e em meios com baixo nível de $\mathrm{N}$ a adição de $\mathrm{P}$ estimulou a germinação dos esporos. O comprimento total das raízes foi estimulado pela adição de $\mathrm{N}$ em meios com baixo nível de $\mathrm{P}$, mas não foi observada diferença significativa entre as concentrações de 10 e $50 \mathrm{mg} / \mathrm{l}$ de $\mathrm{N}$. A adição de $\mathrm{P}$ em meios com baixo nível de $\mathrm{N}$ também estimulou o comprimento total das raízes, observando-se diferença significativa $(\mathrm{p} £ 0,05)$ no comprimento total das raízes entre as concentrações de $\mathrm{P}$ utilizadas. A extensão das raízes colonizadas por G. etunicatum aumentou significativamente $(\mathrm{p} £ 0,05)$ com a adição de $\mathrm{P}$ nos meios com baixo nível de $\mathrm{N}$. Sob baixo nível de $\mathrm{P}$ não foi observada diferença significativa entre a adição de 10 e $50 \mathrm{mg} /$ 1 de N. Os resultados mostram que a interação entre $\mathrm{P}$ e $\mathrm{N}$ afeta diferentemente a germinação de esporos, o crescimento das raízes e a extensão da colonização.

Palavras-chave: Micorriza, Glomus etunicatum, germinação de esporos, colonização de raízes, crescimento de raízes

\section{REFERENCES}

1. Abbott, L.K.; Robson, A.D.; Deboer, G. The effect of phosphorus on the formation of hyphae in soil by the vesicular - arbuscular mycorrhizal fungus, Glomus fasciculatum. New Phytol., 97: 437446, 1984.

2. Amijee, F.; Stribey, D.P.; Tinker, P.B. The development of endomycorrhizal root system. VIII. Effects of soil phosphorus and fungal colonization on the concentration of soluble carbohidrates in roots. New Phytol., 123: 297-306, 1993.

3. Becard, G.; Fortin, J.A. Early events of vesicular-arbuscular mycorrhiza formation on Ri T- DNA transformed roots. New Phytol., 108: 211$218,1988$. 
4. Bolan, N.S.; Robson, A.D.; Barrow, N.J. Increasing phosphorus supply can increase the infection of plant roots by vesicular-arbuscular mycorrhizal fungi. Soil Biol. Biochem., 16: 419-420, 1984.

5. Bruce, A.; Smith, S.E.; Tester, M. The development of mycorrhizal infection in cucumber: effects on root growth, formation of entry points and growth of infection units. New Phytol., 124: 507-514, 1994.

6. Buwalda, J.G.; Goh, K.M. Host-fungus competition for carbon as a case of growth depressions in vesicular-arbuscular mycorrhizal ryegrass. Soil Biol. Biochem., 14: 103-106, 1982.

7. Coxwell, M.A.; Johnson, C.R. Effects of vesicular-arbuscular mycorrhizae and nitrogen source on growth and transport of amino acid composition of Pittosporum tobira. J. Amer. Soc. Hort. Sci., 100: 800-803, 1985.

8. Daniels, B.A.; Trappe, J.M. Factors affecting spore germination of the vesicular-arbuscular mycorrhizal fungus. Phytopatology, 58: 900908, 1980

9. Duncan, W.G.; Ohlrogge, A.J. Principles of nutrient uptake from fertilizer bonds: Root development in the band. Agron. J., 50: 605608,1958

10. Gerdemann, J.W.; Nicolson, T.H. Spores of mycorrhizal Endogone species extracted from soil by wet sieving and decanting. Trans. Br. Mycol. Soc., 46: 235-244, 1963.

11. Gile, P.L.; Carrero, J.O. Absorption of nutrients as affected by the number of roots supplied with the nutrient. J. Agric. Res., 9: 73-95, 1987.

12. Giovannetti, M.; Mosse, B. An evaluation of techniques for measuring vesicular-arbuscular mycorrhizal infection in roots. New Phytol., 84: 489-500, 1980.

13. Harley, J.L.; Smith, S.E. Mycorrhizal symbiosis. Academic Press, London, 1983. 320p.

14. Heijne, B.; Hofstra, J.J.; Heil, G.W.; Dam, D. VAN; Bobink, R. Effect of the air pollution component ammonium sulphate on the VAM infection rate of three heatland species. Plant Soil, 144: 1-12, 1992.

15. Hepper, C.M. The effect of nitrate and phosphate on the vesiculararbuscular mycorrhizal infection of lettuce. New Phytol., 93: 389399,1983

16. Miranda, J.C.C.; Harris, P.J.; Wild, A. Effects of soil and plant phosphorus concentration on vesicular-arbuscular mycorrhiza in sorghum plants. New Phytol., 112: 405-410, 1989.
17. Mosse, B. Advances in the study of vesicular-arbuscular mycorrhiza. Ann. Rev. Phytopathol., 11: 171-196, 1973.

18. Nelsen, C.E.; Bolgiano, N.C.; Furutani, S.C.; Safir, G.R.; Zandstra, B.H. The effect of soil phosphorus levels on mycorrhizal infection of field-grown onion plants and on mycorrhizal reproduction. $J$. Amer. Soc. Hort. Sci., 106: 786-788, 1981.

19. Pearson, J.N.; Schweiger, P. Scutellospora calospora (Nicol. \& Gerd.) Walker \& Sanders associated with subterranean clover products noneffective hyphae during sporulation. New Phytol., 127: 697-701, 1994.

20. Phillips, J.M.; Hayman, H.S. Improved procedures for clearing roots and staining parasitic and vesicular-arbuscular fungi for rapid assesment of infection. Trans. Br. Mycol. Soc., 55: 158-160.

21. Pons, F.; Gianinazzi-Pearson, V. Influence du phosphore, du potassium, dázote et dur le comportement "in vitro" champignons endomycorrhizogenes a vesicules et arbuscules. Cryptogam. Mycol., 5: 87-100, 1984.

22. SAS INSTITUTE. SAS/STAT- User's Guide, Release 6.03, Cary, N.C. 1988

23. Schwab, S.M.; Menge, J.A.; Leonard, R.T. Comparison of stages of vesicular-arbuscular mycorrhiza formation in sudan grass grown at two levels of phosphorus nutrition. Amer. J. Bot., 70: 1225-1232, 1983.

24. Siqueira, J.O.; Sylvia, D.M.; Gibson, J.; Hubbell, D.H. Spore germination and germ tubes growth of vesicular-arbuscular mycorrhizal fungi. Can J. Microbiol., 31: 965-972, 1985.

25. Thomson, B.D.; Robson, A.D.; Abbott, L.K. Effects of phosphorus on the formation of mycorrhizae by Gigaspora calospora and Glomus fasciculatum in relation to root carbohydrates. New Phytol., 103: 751-765, 1986.

26. Thomson, B.D.; Robson, A.D.; Abbott, L.K. Mycorrhizas formed by Gigaspora calospora and Glomus fasciculatum on subterraneum clover in relation to soluble carbohydrates concentrations in roots. New Phytol., 114: 217-225, 1990.

27. Thomson, B.D.; Robson, A.D.; Abbott, L.K. Soil mediated effects of phosphorus supply on the formation of mycorrhizas by Scutellospora calospora (Nicol. \& Gerd.) Walker \& Sanders. New Phytol., 118: 463-469, 1991.

28. Wilson, G.W.T.; Daniels, H.B.A.; Gerschefske, K.D. Supression of vesicular-arbuscular mycorrhizal fungus spore germination in nonsterile soil. Can. J. Bot., 67: 18-23, 1989. 